\title{
A comparison of neutralization efficiency of chemicals with respect to acidic Kopili River water
}

\author{
Nibedita Kapil $^{1}$ - Krishna G. Bhattacharyya ${ }^{2}$
}

Received: 11 June 2015/Accepted: 31 January 2016/Published online: 22 February 2016

(C) The Author(s) 2016. This article is published with open access at Springerlink.com

\begin{abstract}
Among all the renewable sources of energy, hydropower is the most potential source which is economical, non-polluting and eco-friendly. The efficiency of hydropower plant in the long run depends on many factors like water and sediment quality. Erosive and corrosive wear of machine parts like turbine is a complex phenomenon. The problem becomes more acute if the hydroenvironment is acidic in nature. The wear and tear due to corrosion/erosion caused by acid mine drainage (AMD) from coal mines reduces the efficiency and the life of the equipments. In this work, neutralization of the acidic water of the Kopili River, Assam, India was investigated using a number of basic chemicals and quantitatively estimating their effectiveness and actual requirement. The acidic water of the river, used as the cooling water, has been found responsible for damaging the equipments of the Kopili Hydro Electric Power Project (KHEP), Assam/ Meghalaya, India by reducing the life of all metallic parts through corrosion. In this work, use is made of a number of basic materials like calcium carbonate, calcium hydroxide, calcium oxide, sodium carbonate, sodium hydroxide, and ammonia to examine their neutralization efficiency with respect to the acidic water and it was found that quick lime or raw lime $(\mathrm{CaO})$ has the highest neutralization capacity. Suggestions have been made for meeting the problem of acidity of the river water.
\end{abstract}

Krishna G. Bhattacharyya

kgbhattacharyya@gmail.com

1 Department of Chemistry, Assam Don Bosco University, Azara, Guwahati 781017, Assam, India

2 Department of Chemistry, Gauhati University, Guwahati 781014, Assam, India
Keywords Kopili River · Acidic water - Neutralizing agent $\cdot$ Hydropower $\cdot$ Cooling system

\section{Introduction}

Acid mine drainage (AMD), not only most common in coal and metal mining, but also in highway construction and other large-scale excavations, results from exposure of sulphide minerals to oxidizing conditions. The oxidized sulphur minerals form acidic sulphate-rich drainage. The type and quantity of sulphide minerals present determines the metal composition and concentration in AMD. Generally, sulphide-rich and carbonate-poor materials produce acidic drainage. Iron sulphides are most common but other metal sulphides may also produce AMD in the presence of water and oxygen. Metal contamination associated with AMD depends on the type and amount of sulphide mineral oxidized, as well as the type of gangue minerals present in the rock. About $90 \%$ of the AMD reaching streams originate in abandoned surface and deep mines (Skousen et al. 2000). The acidic sulphur-rich wastewaters may also arise from the by-products of a variety of industrial operations such as galvanic processing and the scrubbing of flue gases at power plants (Johnson 2000).

The acidic waters have the additional risk of carrying elevated concentrations of metals (iron, aluminium and manganese, and possibly other heavy metals) and metalloids to the environment resulting from the exposure of the minerals to both oxygen and water (Johnson and Hallberg 2005). The $\mathrm{pH}$ of the AMD may be as low as $2-3$, and at this low $\mathrm{pH}$, the AMD contains high concentrations of metals such as $\mathrm{Fe}, \mathrm{Mn}, \mathrm{Al}$ and anions, e.g., $\mathrm{SO}_{4}{ }^{2-}$, as well as increased concentrations of $\mathrm{Zn}, \mathrm{Co}, \mathrm{Pb}, \mathrm{Cr}$, and $\mathrm{Cu}$.

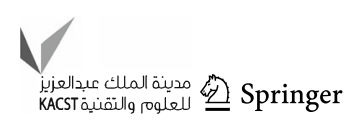


When AMD contaminates groundwater, severe risk may be generated as in the case of the Wheal Jane mine in 1992 (Neal et al. 2004; Younger et al. 2005). It is, therefore, important that appropriate technologies are developed for treatment of AMD. The treatment must result in such water that sustains various organisms in water and make the water suitable for its innumerous uses (Heviánková et al. 2011, 2013). Some common techniques include limestone and lime treatment, biological sulphate reduction and passive treatment in alkalinity generating artificially constructed wetlands. The most widespread method used to mitigate acidic effluents is an active treatment process involving addition of a chemical-neutralizing agent (Coulton et al. 2003). Highly soluble magnesite, $\mathrm{MgSO}_{4}$, has been found suitable for selectively precipitating metal hydroxides by raising the pH to 10 (Masindi et al. 2014).

In the present work, the problem arising from the corrosion damages caused by the strongly acidic Kopili River water on various metal parts of the Kopili Hydro Electric Power Project (KHEP), Assam/Meghalaya, India and the treatment of the acidic water by chemical neutralization have been investigated. It is observed that the water in the reservoir of the plant is acidic and the degree of acidity varies with time. Wear and tear of sensitive metallic parts of the plants registered a steep rise during the last few years and concern has been expressed about the longevity of the major structure and equipments of the plant. The plant had to replace the $90: 10 \mathrm{Cu} / \mathrm{Ni}$ cooler tubes with $70: 30 \mathrm{Cu} / \mathrm{Ni}$ recently, but the damages are still there. There has also been acute hazard to the biotic environment in the area, visibly marked by the conspicuous absence of aquatic fauna in the river.

The present work, therefore, evaluates the performance of potential neutralizing chemicals to address the problem of acidic water of the Kopili River.

\section{Materials and methods}

\section{Study area and description of the sampling site}

The Kopili HE Plant (KHEP) of North Eastern Electric Power Corporation Limited (NEEPCO Ltd) is a $275 \mathrm{MW}$ storage type hydroelectric power plant constructed on the river Kopili, a major tributary of the river Brahmaputra. The Khandong Dam of KHEP intercepts the flow of the Kopili River and retains the water in the Kopili reservoir. Khandong Power Station $(2 \times 25 \mathrm{MW})$ and Kopili Stage II Power Station $(1 \times 25 \mathrm{MW})$ draw water from the Kopili reservoir. The water is discharged to the Umrong reservoir. Kopili Power Station $(4 \times 50 \mathrm{~W})$ draw water from the Umrong Reservoir via Umrong Water Conductor System for producing electricity and finally the water is discharged into the Kopili River. Figure 1 shows the layout of KHEP.

Standard chemicals and methods (APHA 2005) were used (1) to determine acidity of the water used in the Power Stations, (2) for preparation of simulated acidic water in the laboratory as is used in the Plants, (3) for detailed neutralization experiments with the acidic water in batch reactors with alkaline materials and in various

Fig. 1 The KHEP layout

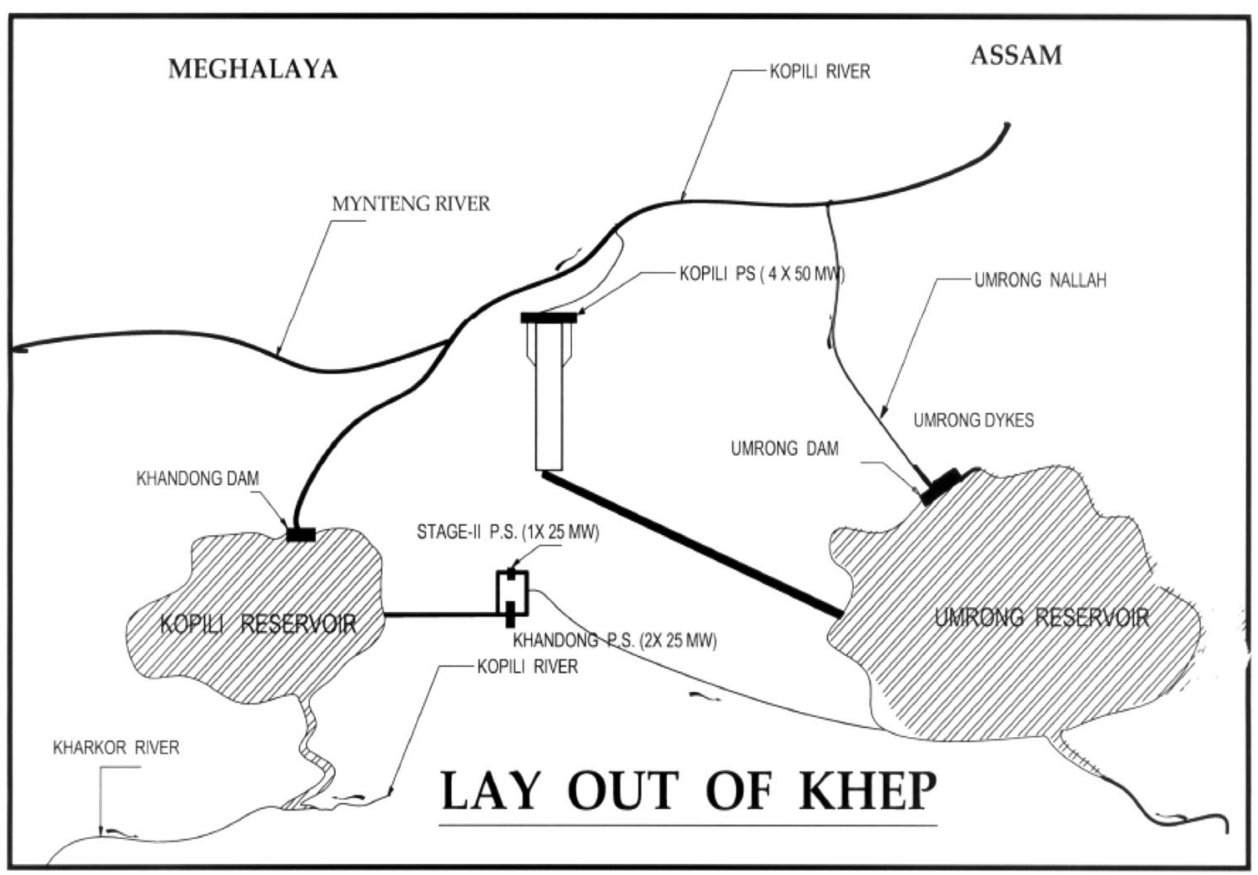


Table 1 Requirement of base for neutralization of Plant water (pH: 3.2)

\begin{tabular}{llllll}
\hline Base & Normality $(\mathrm{N})$ & Base required $(\mathrm{mL})$ & Sample water $(\mathrm{mL})$ & $\mathrm{pH}$ & Amount of base required for neutralization $\left(\mathrm{g} / \mathrm{m}^{3}\right)$ \\
\hline $\mathrm{NaOH}$ & 0.05 & 2.6 & 100 & 6.7 & 52.0 \\
$\mathrm{Na}_{2} \mathrm{CO}_{3}$ & 0.01 & 8.0 & 100 & 6.6 & 84.8 \\
\hline
\end{tabular}

Table 2 Requirement of base for neutralization of simulated acidic water ( $\mathrm{pH} 3.2$ )

\begin{tabular}{|c|c|c|c|c|c|}
\hline \multirow[t]{2}{*}{ Normality $(\mathrm{N})$ of $\mathrm{H}_{2} \mathrm{SO}_{4}$ added } & \multirow[t]{2}{*}{ Water $(\mathrm{mL})$} & \multicolumn{2}{|c|}{$\mathrm{pH}$ of water } & \multirow[t]{2}{*}{ Acid added (mL) } & \multirow[t]{2}{*}{ Base required to neutralize $\left(\mathrm{g} / \mathrm{m}^{3}\right)$} \\
\hline & & Initial & Final & & \\
\hline 0.01 & 100.0 & 6.4 & 3.2 & 4.5 & $38.2\left(\mathrm{Na}_{2} \mathrm{CO}_{3}\right)$ \\
\hline 0.01 & 100.0 & 6.4 & 3.2 & 4.5 & $20.0(\mathrm{NaOH})$ \\
\hline
\end{tabular}

Table 3 Neutralization of Plant water ( $\mathrm{pH}$ 3.4) with raw lime

\begin{tabular}{lllll}
\hline Water $(\mathrm{mL})$ & Normality $(\mathrm{N})$ & Base required $(\mathrm{mL})$ & $\mathrm{pH}$ & Amount of neutralizing base $\left(\mathrm{g} / \mathrm{m}^{3}\right)$ \\
\hline 500.0 & 0.1 & 1.7 & 5.0 & 4.8 \\
500.0 & 0.1 & 2.1 & 6.2 & 5.9 \\
500.0 & 0.1 & 2.2 & 7.1 & 6.2 \\
\hline
\end{tabular}

combinations to evaluate the neutralization efficiency. Laboratory-grade basic materials, namely calcium carbonate $\left(\mathrm{CaCO}_{3}\right)$, calcium hydroxide $\left(\mathrm{Ca}(\mathrm{OH})_{2}\right)$, calcium oxide $(\mathrm{CaO})$, sodium carbonate $\left(\mathrm{Na}_{2} \mathrm{CO}_{3}\right)$, sodium hydroxide $(\mathrm{NaOH})$, and ammonia $\left(\mathrm{NH}_{3}\right)$ were used for acid neutralization.

Neutralization experiments were conducted by taking $500 \mathrm{~mL}$ of the water sample in a 1-L beaker followed by addition of pre-weighed quantities of the bases listed above with continuous stirring. The $\mathrm{pH}$ was measured at each stage of addition and the amount of base required to reach $\mathrm{pH}$ of (a) 5.0, (b) 6.0 and (c) 7.0 was found (Systronics Model 335 Digital pH meter).

\section{Results and discussion}

\section{Neutralization of the plant water}

(i) Neutralization experiments with sodium hydroxide $(\mathrm{NaOH})$ and sodium carbonate $\left(\mathrm{Na}_{2} \mathrm{CO}_{3}\right)$

The preliminary experiments showed that to neutralize $1 \mathrm{cu}$ m of plant water ( $\mathrm{pH} 3.2), 52 \mathrm{~g}$ of $\mathrm{NaOH}$ and $84.8 \mathrm{~g}$ of $\mathrm{Na}_{2} \mathrm{CO}_{3}$ (Table 1) would be sufficient to bring up the $\mathrm{pH}$ of the supplied water to near neutral range that could be used safely.

A second set of experiments done with simulated acidic water of the same $\mathrm{pH}$ as the plant water $(\mathrm{pH} 3.2)$ showed that $1 \mathrm{cu} \mathrm{m}$ of distilled water acidified with $\mathrm{H}_{2} \mathrm{SO}_{4}$ to $\mathrm{pH}$ 3.2 needs $20.0 \mathrm{~g}$ of $\mathrm{NaOH}$ and $38.2 \mathrm{~g}$ of $\mathrm{Na}_{2} \mathrm{CO}_{3}$ (Table 2) to bring up the $\mathrm{pH}$ to near neutral range. The much smaller requirement of base in this case shows that the actual Plant water due to the presence of various other salts, etc., requires a large dose of base to come to the same level of neutralization.

(ii) Neutralization experiments with calcium oxide $(\mathrm{CaO})$ (raw lime)

In this set, neutralization of the Plant water is done with addition of raw lime $(\mathrm{CaO})$ following the same procedure and the results are shown in Table 3 . The base is added in the form a suspension in distilled water to obtain $0.1 \mathrm{~N}$ strength and the amount of base required to reach three different stages of neutralization ( $\mathrm{pH} \mathrm{5.0,6.2} \mathrm{and} \mathrm{7.1)} \mathrm{is}$ found out. It is observed that the raw lime requirement (4.8-6.2 $\mathrm{g}$ for $1 \mathrm{cu} \mathrm{m}$ of Plant water) is much lower compared to those of $\mathrm{NaOH}$ or $\mathrm{Na}_{2} \mathrm{CO}_{3}$. Thus, raw lime will be a cheaper alternative in neutralizing acidic Plant water.

In a separate set of experiments, the raw lime suspension in water is filtered and the filtrate is used to neutralize the Plant water. The results are shown in Table 4. Now, a much larger amount of lime is necessary (39.2 to $43.4 \mathrm{~g}$ for $1 \mathrm{cu} \mathrm{m}$ of Plant water and the values are in the range of $\mathrm{NaOH}$ or $\mathrm{Na}_{2} \mathrm{CO}_{3}$ requirement.

(iii) Neutralization experiments with calcium carbonate $\left(\mathrm{CaCO}_{3}\right)$

The results of neutralization experiments with lime stone or calcium carbonate suspension in water are 
Table 4 Neutralization of Plant water ( $\mathrm{pH}$ 3.2) with filtrate of raw lime suspension

\begin{tabular}{lllll}
\hline Water $(\mathrm{mL})$ & Normality $(\mathrm{N})$ & Base required $(\mathrm{mL})$ & $\mathrm{pH}$ & Amount of neutralizing base $\left(\mathrm{g} / \mathrm{m}^{3}\right)$ \\
\hline 100.0 & 0.1 & 2.8 & 5.2 & 39.2 \\
100.0 & 0.1 & 3.0 & 6.1 & 42.0 \\
100.0 & 0.1 & 3.1 & 7.2 & 43.4 \\
\hline
\end{tabular}

Table 5 Neutralization of Plant water ( $\mathrm{pH}$ 3.7) with calcium carbonate suspension

\begin{tabular}{llllr}
\hline Water $(\mathrm{mL})$ & Normality $(\mathrm{N})$ & Base required $(\mathrm{mL})$ & $\mathrm{pH}$ & Amount of neutralizing base $\left(\mathrm{g} / \mathrm{m}^{3}\right)$ \\
\hline 500 & 0.1 & 0.2 & 4.8 & 4.0 \\
500 & 0.1 & 0.3 & 6.0 & 6.0 \\
500 & 0.1 & 0.7 & 7.2 & 14.0 \\
\hline
\end{tabular}

Table 6 Neutralization of Plant water $(\mathrm{pH} 3.8)$ with hydrated lime $\left(\mathrm{Ca}(\mathrm{OH})_{2}\right)$

\begin{tabular}{lllll}
\hline Water $(\mathrm{mL})$ & Normality $(\mathrm{N})$ & Base required $(\mathrm{mL})$ & $\mathrm{pH}$ & Amount of neutralizing base $\left(\mathrm{g} / \mathrm{m}^{3}\right)$ \\
\hline 500 & 0.1 & 0.9 & 5.0 & 13.3 \\
500 & 0.1 & 1.7 & 6.4 & 25.2 \\
500 & 0.1 & 1.9 & 7.1 & 28.2 \\
\hline
\end{tabular}

presented in Table 5. The requirement of limestone is shown at three stages of neutralization corresponding to $\mathrm{pH} 4.8,6.0$, and 7.2 and it is seen that the limestone requirement is $4.0,6.0$ and $14.0 \mathrm{~g}$, respectively, for $1 \mathrm{cu} \mathrm{m}$ of Plant water. The results indicate that $\mathrm{CaCO}_{3}$ is as effective as $\mathrm{CaO}$ in the neutralization process of the Plant water and an amount of $14.0 \mathrm{~g}$ will be required for each $\mathrm{cu} \mathrm{m}$ of Plant water for complete neutralization.

(iv) Neutralization experiments with hydrated lime, calcium hydroxide, $\mathrm{Ca}(\mathrm{OH})_{2}$

This set of experiments that uses calcium hydroxide as the neutralizing base has the results given in Table 6 . Compared to raw lime or lime stone, the amount of $\mathrm{Ca}(\mathrm{OH})_{2}$ needed to reach the same state of neutralization is high (13.3 to $28.2 \mathrm{~g}$ for $1 \mathrm{cu} \mathrm{m}$ of Plant water to reach $\mathrm{pH}$ of 5.0, 6.4 and 7.1, respectively).

\section{Comparative study of neutralization}

After the preliminary set of experimentation as described above, the neutralization experiments were repeated in a comprehensive scale with several sets of experiments. The averages of the results obtained are given in Table 7 which present a comparative study of the five bases with respect to their neutralization capacity.

\section{Requirements of chemicals for acidity neutralization}

It is seen that the amount of base required for neutralization depends on the initial $\mathrm{pH}$. Even a slight variation in the initial $\mathrm{pH}$ may alter the results. On the basis of the data in Table 8 , it is found that the neutralizing bases can be arranged in the following order with respect the amount required to achieve complete neutralization ( $\mathrm{pH} 7.0)$ :

$\mathrm{CaCO}_{3}>\mathrm{Na}_{2} \mathrm{CO}_{3}>\mathrm{NaOH}>\mathrm{Ca}(\mathrm{OH})_{2}>\mathrm{CaO}$.

Quick lime or raw lime $(\mathrm{CaO})$ has the highest neutralization capacity while limestone has the minimum neutralization capacity among the bases used. The amount of the base required by $1 \mathrm{cu} \mathrm{m}$ of the Plant water ( $\mathrm{pH} 3.2)$ is as follows:

\begin{tabular}{lll}
\hline 1 & $\mathrm{CaCO}_{3}$ & $45.41 \mathrm{~g}$ \\
2 & $\mathrm{Na}_{2} \mathrm{CO}_{3}$ & $37.10 \mathrm{~g}$ \\
3 & $\mathrm{NaOH}$ & $20.00 \mathrm{~g}$ \\
4 & $\mathrm{Ca}(\mathrm{OH})_{2}$ & $18.52 \mathrm{~g}$ \\
5 & $\mathrm{CaO}$ & $17.94 \mathrm{~g}$ \\
\hline
\end{tabular}

It may be noted that the differences among the last three bases are not much. The choice of a suitable material for acidity neutralization will also depend on the cost and since 
Table 7 Comparative study of requirement of neutralizing base ( $0.1 \mathrm{M}$ suspension/solution in distilled water) for neutralization of Plant water to different stages of $\mathrm{pH}$

\begin{tabular}{|c|c|c|c|c|}
\hline $\mathrm{S} / \mathrm{N}$ & Base & Initial $\mathrm{pH}$ & Final pH & Base requirement $\left(\mathrm{g} / \mathrm{m}^{3}\right)$ \\
\hline 1 & \multirow[t]{3}{*}{$\mathrm{CaO}$ (Quick Lime, Calcium oxide) } & 3.7 & 5.0 & 10.65 \\
\hline 2 & & 3.7 & 6.0 & 16.82 \\
\hline 3 & & 3.7 & 7.2 & 17.94 \\
\hline 4 & \multirow[t]{3}{*}{$\mathrm{Ca}(\mathrm{OH})_{2}$ (Hydrated Lime, Calcium Hydroxide) } & 3.7 & 5.1 & 13.34 \\
\hline 5 & & 3.7 & 6.2 & 17.78 \\
\hline 6 & & 3.7 & 7.2 & 18.52 \\
\hline 7 & \multirow[t]{3}{*}{$\mathrm{CaCO}_{3}$ (Limestone, Calcium Carbonate) } & 3.7 & 5.0 & 13.01 \\
\hline 8 & & 3.7 & 6.1 & 32.03 \\
\hline 9 & & 3.7 & 7.2 & 45.41 \\
\hline 10 & \multirow[t]{3}{*}{$\mathrm{Na}_{2} \mathrm{CO}_{3}$ (Soda Ash, Sodium Carbonate) } & 3.7 & 5.0 & 20.14 \\
\hline 11 & & 3.7 & 6.2 & 27.56 \\
\hline 12 & & 3.7 & 7.1 & 37.10 \\
\hline 13 & \multirow[t]{3}{*}{ NaOH (Caustic Soda, Sodium Hydroxide) } & 3.8 & 5.0 & 14.40 \\
\hline 14 & & 3.8 & 6.3 & 19.20 \\
\hline 15 & & 3.8 & 7.2 & 20.00 \\
\hline
\end{tabular}

Table 8 Requirement of quick lime $(\mathrm{CaO})$ for neutralization up to $\mathrm{pH} 7.0$

\begin{tabular}{|c|c|c|c|c|c|}
\hline \multirow[t]{2}{*}{$\mathrm{S} / \mathrm{N}$} & \multicolumn{2}{|c|}{$\begin{array}{l}\text { Water } \\
\text { requirement }\end{array}$} & \multicolumn{2}{|c|}{$\begin{array}{l}\text { Chemical } \\
\text { quantity }\end{array}$} & \multirow[t]{2}{*}{ Total requirement $(\mathrm{kg} / \mathrm{h})$} \\
\hline & LPM & $\mathrm{Cu} \mathrm{m/h}$ & $\mathrm{g} / \mathrm{cu} \mathrm{m}$ & $\mathrm{kg} / \mathrm{cu} \mathrm{m}$ & \\
\hline \multicolumn{6}{|c|}{ A. Kopili Power Station } \\
\hline 1 & 24000 & 1440 & 17.94 & 0.01794 & 25.8 \\
\hline 2 & 2160 & 130 & 17.94 & 0.01794 & 2.3 \\
\hline 3 & 2160 & 130 & 17.94 & 0.01794 & 2.3 \\
\hline 4 & 6720 & 403 & 17.94 & 0.01794 & 7.2 \\
\hline 5 & 1200 & 72 & 17.94 & 0.01794 & 1.3 \\
\hline 6 & 400 & 24 & 17.94 & 0.01794 & 0.4 \\
\hline 7 & 4320 & 259 & 17.94 & 0.01794 & 4.7 \\
\hline Total & 40960 & 2458 & 125.58 & 0.12558 & 44.0 \\
\hline \multicolumn{6}{|c|}{ B. Khongdon Power Station } \\
\hline 1 & 6400 & 384 & 17.94 & 0.01794 & 6.9 \\
\hline 2 & 300 & 18 & 17.94 & 0.01794 & 0.3 \\
\hline 3 & 1600 & 96 & 17.94 & 0.01794 & 1.7 \\
\hline 4 & 1500 & 90 & 17.94 & 0.01794 & 1.6 \\
\hline 5 & 160 & 10 & 17.94 & 0.01794 & 0.2 \\
\hline 6 & 480 & 29 & 17.94 & 0.01794 & 0.5 \\
\hline Total & 10440 & 627 & 17.94 & 0.01794 & 11.2 \\
\hline \multicolumn{6}{|c|}{ C. Stage II Power Station } \\
\hline 1 & 3200 & 192 & 17.94 & 0.01794 & \\
\hline 2 & 150 & 9 & 17.94 & 0.01794 & 3.4 \\
\hline 3 & 800 & 48 & 17.94 & 0.01794 & 0.2 \\
\hline 4 & 750 & 45 & 17.94 & 0.01794 & 0.9 \\
\hline 5 & 80 & 5 & 17.94 & 0.01794 & 0.8 \\
\hline 6 & 240 & 14 & 17.94 & 0.01794 & 0.1 \\
\hline Total & 5220 & 313 & 17.94 & 0.01794 & 5.7 \\
\hline
\end{tabular}

limestone is locally available and cheaper than the other materials, it may be the ideal choice for neutralization.

Based on actual cooling water requirement of the Plants, the chemical requirement for neutralization is presented in Table 8 .

The work further established that the lowering of the $\mathrm{pH}$ of Kopili River water is due to release of AMD (acid mine drainage) in a diffuse manner from a large number of small and medium coal mines in the catchment area. The strongly acidic Kopili River water has damaged the machines of the Kopili Hydro Electric Power Project (KHEP), Assam, India through heavy corrosion and the KHEP units have suffered rapid wear and tear of the metallic parts arising from the acidic cooling water. This has resulted in a decreasing efficiency of the coolers leading to damage/failure of the main equipments. The cooling water pipelines and valves are getting corroded rapidly creating serious problems of frequent failure and costly replacement. The damages to the ecology and the human habitation in the nearby areas dependent on the Kopili River water have not been estimated and the low $\mathrm{pH}$ of the water might have solubilised various heavy metals from the rocks making the water hazardous to humans as well as all forms of life.

It is suggested that some field trials be conducted by adding the basic chemical before the trash rack, i.e., before the water enters into the circulation system. It may be noted that the choice of a suitable basic material for acidity neutralization will depend on the cost. Since limestone is widely available in Karbi Anglong and nearby areas of Assam and is also cheaper than the other materials, it may be the ideal choice for neutralization. Ideally the material 
should be added at the storage pond with facilities for continuous stirring and agitation (so that the base quickly interacts with the acidity) and the neutralized water should go to circulation.

Acknowledgments This project was sponsored by the North Eastern Electric Power Corporation Limited (NEEPCO Ltd), India.

Open Access This article is distributed under the terms of the Creative Commons Attribution 4.0 International License (http:// creativecommons.org/licenses/by/4.0/), which permits unrestricted use, distribution, and reproduction in any medium, provided you give appropriate credit to the original author(s) and the source, provide a link to the Creative Commons license, and indicate if changes were made.

\section{References}

APHA (2005) Standard methods for the examination of water and wastewater, 21st edn. American Public Health Association, 2005, Washington, D.C

Coulton R, Bullen C, Hallet C (2003) The design and optimization of active mine water treatment plants. Land Contam Reclam 11:273-279

Heviánková S, Bestová I, Zechner M (2011) Possibilities of Acid mine Drainage Treatment in Sokolovská uhelná, Czech Republic, Gospodarka Surowcami Mineralnymi, Kwartalnik Tom 27Zeszyt 3,Wydawnictwo IGSMiE PAN, Kraków, PL ISSN 0860-0953, pp 113-123
Heviánková S, Sestová I, Kyncl M, Simková L, Zechner M (2013) Calcium Carbonate as an Agent in Acid Mine Water Neutralization, Inżynieria Mineralna-LIPIEC-GRUDZIEŃ. J Pol Miner Eng Soc 159-166

Johnson DB (2000) Biological removal of sulfurous compounds from inorganic wastewaters. In: Lens P, Hulshoff Pol L (eds) Environmental Technologies to Treat Sulfur Pollution: Principles and Engineering. London 7 International Association on Water Quality, pp 175-206

Johnson DB, Hallberg KB (2005) Acid mine drainage remediation options: a review. Sci Total Environ 338:3-14

Masindi V, Gitari WM, Tutu H, De Beer M, Nekhwevha N (2014) Neutralization and Attenuation of Metal Species in Acid Mine Drainage and Mine Leachates Using Magnesite: a Batch Experimental Approach. An Interdisciplinary Response to Mine Water Challenges-Sui, Sun \& Wang (eds). China University of Mining and Technology Press, Xuzhou, ISBN 978-7-5646-24378640

Neal C, Whitehead PG, Jeffery H, Neal M (2004) The water quality of the River Carnon, West Cornwall, November 1992 to March 1994: the impacts of Wheal Jane discharges. Sci Total Environ 338:23-39

Skousen JG, Sexstone A and Ziemkiewicz PF (2000) Acid mine drainage control and treatment. Reclamation of drastically disturbed lands. American Society of Agronomy and American Society for Surface Mining and Reclamation. Agronomy No. 41, Chapter 6, p 42

Younger PL, Coulton RH, Froggatt EC (2005) The contribution of science to risk-based decision-making: lessons from the development of full-scale treatment measures for acidic mine waters at Wheal Jane, UK. Sci Total Environ 338:137-154 